\title{
Liquefaction potential of sand tailings dams evaluated using a probabilistic interpretation of estimated in-situ relative density
}

\section{Evaluación del potencial de licuefacción en tranques de arena de relaves empleando una interpretación probabilística de la densidad relativa estimada in-situ}

\section{Gabriel Villavicencio A. (Main and Contact Author)}

Pontificia Universidad Católica de Valparaíso / Escuela de Ingeniería en Construcción/Grupo de Geotecnia, Chile Avenida Brasil № 2147. Valparaíso. Chile, +56-32273751 / +56-32-2273808

gabriel.villavicencio@pucv.cl

\section{Pierre Breul}

Clermont Université. Université Blaise Pascal. Institut Pascal, Clermont-Ferrand. CNRS pierre.breul@univ-bpclermont.fr

\section{Claude Bacconnet}

Clermont Université. Université Blaise Pascal. Institut Pascal, Clermont-Ferrand. CNRS claude.bacconnet@univ-bpclermont.fr

\section{Andy Fourie}

University of Western Australia, Environmental and Mining Engineering, School of Civil School of Civil, andy.fourie@uwa.edu.au

\section{Raúl Espinace A.}

Pontificia Universidad Católica de Valparaíso/ Escuela de Ingeniería en Construcción/Grupo de Geotecnia respinac@pucv.cl

Manuscript Code: 235

Date of Acceptance/Reception: 01.08.2016/27.09.2014

\begin{abstract}
In Chile, sand tailings dams represent the most common deposits of mining residues. These structures present a potential risk in terms of mechanical instability due to their potential susceptibility to seismic liquefaction. In order to manage these risks, it is necessary to take a probabilistic approach, thus accounting for inherent variability of material properties. However, in practice, implementing such an approach is impeded by the difficulty of acquiring and managing the data to be used in the reliability calculations and is conditioned by the relevance of the probabilistic models chosen to represent this variability. This paper proposes a method for onsite determination of the tailings relative density (DR\%), and its variability, using dynamic penetration tests. This method was applied to typical Chilean sand tailings dams, and proposes a single model for all such tailings dams by associating a probability model to the variation of DR\%. Finally, the validity of this approach is demonstrated by performing a reliability calculation of liquefaction potential (which is the main cause for the failure of this type of structure in this country) for a particular sands tailing dam.
\end{abstract}

Keywords: cone penetrometer test; relative density; liquefaction; sand tailings dams.

Resumen

En Chile los tranques de arenas de relaves representan los depósitos de residuos mineros más comunes. Estas estructuras presentan un potencial riesgo en términos de inestabilidad mecánica debido al fenómeno de la licuefacción sísmicamente inducida. Para conocer este riesgo, es necesario considerar una aproximación probabilística. Sin embargo, en la práctica, la implementación de estas aproximaciones es muy limitada, debido la dificultad obtener los datos necesarios para los cálculos de fiabilidad, y a la selección de los modelos probabilísticos necesarios para representar su variabilidad. Este artículo propone un método para estimar in-situ la densidad relativa (DR\%) en arena de relaves y su variabilidad, a partir de ensayos de resistencia a la penetración dinámica. El método se aplica en tranques de arena de relaves chilenos, proponiendo un único modelo para la función de probabilidad del parámetro DR\%. Finalmente, el interés de esta aproximación se demuestra mediante un cálculo de fiabilidad del potencial riesgo de licuefacción, correspondiente a la principal causa de falla en países sísmicamente activos como Chile. 
In Chile, sand tailings dams represent the most common deposits of mining residues. This is the case for copper, for which the coarse fraction (fine sands) of the tailings form the body of the dams, while the fine saturated fraction (sludge and silts) is poured by cycloning into the reservoirs of the dams thus formed. Chile has a very large number of tailings dams built in this way. A survey done in 2010 by the National Service of Geology and Mining (SERNAGEOMIN) showed the existence of 449 deposits of tailings, mainly distributed in the northern and central regions of Chile. Approximately $70 \%$ of them were dams constructed using cycloned sands tailing (Villavicencio, Espinace, Palma, Fourie, \& Valenzuela, 2014). Due to the construction methods and materials used, these dams have historically been associated with some catastrophic failures. In Chile, failures have mainly occurred due to seismic liquefaction with flow failure (true liquefaction), slope instabilities with seismically induced deformations, and overtopping (Villavicencio et al., 2014).

These failures pose major risks for the surrounding populations and the surrounding environment. In order to provide a robust strategy for managing the potential liquefaction risk, use of a probabilistic approach is an attractive option. However, applying such an approach in practice is limited by the difficulty of obtaining and managing the data (random variables and stochastic fields) to be introduced into the reliability calculations and is conditioned by the relevance of the probability models chosen to represent the variability of sand tailings dam properties (Villavicencio, Breul, Bacconnet, Boissier \& Espinace, 2011; Villavicencio, Breul, Espinace \& Valenzuela, 2012). In this article, we propose a method to estimate on site the sand tailings relative density (DR\%) and its variability, using dynamic penetration tests. This method, applied to Chilean dams constructed from copper sand tailings, proposes a single model for all such sand tailings dams to associate a probability law to the DR\%. Finally, the validity of this approach is illustrated for the case of a simple probabilistic estimation of the liquefaction potential, which is dependent on the $\mathrm{DR} \%$, and which is the main cause of sand tailings dam failures in countries with high seismic activity.

\section{Description of the problem: sand tailings dams risk and actual state in Chile}

From the analysis of 38 failures of sand tailings dams recorded in Chile, between the beginning of the 20th century until 2013, Villavicencio et al. (2014) concluded that seismic liquefaction was responsible for $50 \%$ of cases, slope instability due to seismic strain for $32 \%$ and overtopping for $18 \%$. Liquefaction occurs principally in sand tailings dams built with the "upstream" method and for dams of 5 to $35 \mathrm{~m}$ high. Moreover, this phenomenon was especially observed for the low and middle sized mining companies with a copper production capacity less than 3.000 .000 ton/year. During the 1965, 1981, 1985 and 2010 earthquakes, in the region of Valparaiso, liquefaction occurred due to the same factors: lack of compaction, inappropriate geometry (dam slopes greater than $1.7: 1 ; \mathrm{H}: \mathrm{V}$ ), saturation of the sand tailings due to significant rainfall events and poor control of the slimes in the storage area.

During the past 40 years, Chilean standards (Supreme Decree DS № 96 of 1970 and DS № 248 of 2007), which govern engineering practice, proposed an improvement in the design and construction of sand tailings dams. Sand tailings dams have to be less than $250 \mathrm{~m}$ high and adhere to construction rules adapted for seismic loading (as observed during the 2010 earthquake in the Region of Maule, Chile). However, the low and middle sized mining companies are generally not able to carry out these rules of construction. This is a key reason why a disproportionately high number of the 314 Chilean sand tailings dams (SERNAGEOMIN, 2010), have a high risk of instability and an unknown safety factor.

State of the art

\section{In situ estimation of relative density (DR\%)}

\section{Objectives}

In sand tailings with non plastic fines (size $<75 \mu \mathrm{m}$ ) the relative density (DR\%) is a very important parameter, and is related to the in situ penetration strength ( $N, q d, q c$, etc), thus enabling a preliminary study of the static and dynamic stability of sand tailings dams and the evaluation of the liquefaction potential (Troncoso, 1986). It provides an initial estimate of the state of compaction and of the associated mechanical behavior: dilatant or contractant.

The relative density (DR\%) is greatly influenced by the physical and mineral characteristics of the particles (percentage $<75 \mu \mathrm{m}$ ), the arrangement of the grains and by the level of stress in-situ. Studies conducted by Troncoso (Troncoso, 1986) concluded that for sand tailings with a percentage of fines around $15 \%$, with confining stress between $50 \mathrm{kPa}$ 
and $350 \mathrm{kPa}$, a relative density (DR\%) below $50 \%-60 \%$ is an indicator of contraction (densification). Under this condition, if the material is saturated or partially saturated, under seismic conditions the risk of liquefaction is real. On the other hand, the material will tend to a dilatant behavior for a relative density above these values. Verdugo \& Bard (1995) and Verdugo (1997) conducted an analysis of the variation of the minimum and maximum densities (Vibratory and Proctor compaction) both with sand tailings and similar soils (sands and silts) with different percentages of fines. They concluded that an in situ relative density of $60 \%$ is a very reasonable compaction value, with a satisfactory mechanical behavior (dilatant) in structures that allow a certain degree of deformation, such as sand tailings dams. It should be emphasized that these criteria apply to the sand tailings for which they were derived; they do not, for example, necessarily apply to thickened tailings, which are usually non-segregating, thus resulting in a deposit generally having higher fines contents throughout the sand tailings dams. Thus to be able to estimate DR\% in situ, as well as its variability is important for evaluating the mechanical behavior of sand tailings. In the following section of this paper a method of estimating DR\%, based on penetration resistance is proposed.

\section{Relations proposed for estimating relative density (DR\%)}

Estimating relative density (DR\%) from the dynamic (qd) or static (qc) cone penetration resistance using empirical and semi-empirical relations, requires first normalizing $\mathrm{qd}$ and $\mathrm{q}_{\mathrm{c}}$ by a reference stress corresponding to atmospheric pressure $(1.0 \mathrm{~atm} \approx 100 \mathrm{kPa} \approx 0.10 \mathrm{MPa}$ ), using equation 1 . According to Moss, Seed, Kayen, Stewart, \& Der Kiureghian (2006), this reference stress value is considered as reasonable if the depth/stress relation is taken into account.

$$
\mathrm{qc}_{1}=\mathrm{qc} \cdot \mathrm{C}_{\mathrm{q}} \quad \text { with } \quad \mathrm{C}_{\mathrm{q}}=\left(\mathrm{p}_{\mathrm{a}} / \sigma_{\mathrm{v}}^{\prime}\right) \mathrm{c}
$$

Where: $\mathrm{qc}_{1}=$ normalized cone resistance $(\mathrm{kPa}) ; \mathrm{qc}=$ cone resistance $(\mathrm{kPa}) ; \mathrm{C}_{\mathrm{q}}=$ normalization coefficient; $\mathrm{p}_{\mathrm{a}}=$ atmospheric pressure (1.0 atm); $\sigma^{\prime}{ }_{v}=$ effective vertical stress in atmospheric units; $c=$ normalization exponent.

According to Salgado, Boulanger, \& Mitchell (1997) and Moss et al. (2006), the normalization coefficient is not only linked to the intrinsic properties of the soil (mineralogy, granulometry and particle shape and texture characteristics), but also to its state variables such as lateral pressure, cementation, vertical effective stress $\left(\sigma^{\prime}{ }_{v}\right)$, mainly depends on the relative density (DR\%) of the material. On the basis of studies performed by Olsen \& Mitchell (1995) and Salgado et al. (1997), by considering the nature and variability of the state of compaction expected of sand tailings in situ, we used a value ranging from 0.5 to 0.75 for the normalization exponent "c".

Other works have highlighted the existence of a relation between relative density (DR\%) and static cone resistance (qc) for sands whose physical properties are close to those of the sand tailings studied here (Tatsuoka, Zhou, Sato, \& Shibuya, 1990). These relations have been established on the basis of tests performed in a calibration chamber. From these studies, using static cone penetration resistance tests to obtain DR\% may be viable but the precise estimation of the variability of DR\% requires a large number of drillings. However, due to the constraints relating to this test, the number of soundings performed for each site is often limited. This is why we have developed a method for obtaining $\mathrm{DR} \%$ based on dynamic cone penetration resistance measurements (qd).

Methodology

\section{Estimation of relative density (DR\%) from dynamic cone resistance measurements (qd)}

Our study is based on the use of the dynamic cone penetration resistance (qd) parameter used as a random variable, which is obtained by using the Panda test. The Panda device is a manual, light, dynamic penetrometer with variable energy and a small cone section ( 2.0 or $4.0 \mathrm{~cm} 2$ ) (Chaigneau, 2001; Villavicencio et al., 2012), which provides the cone resistance qd of the soil as a function of depth, and is capable of performing a large number of tests in situ thanks to its small size and its quick implementation. This device can operate to a depth of $6 \mathrm{~m}$ and for materials having particles smaller than $50 \mathrm{~mm}$. It is possible to measure soil resistance up to 30MPa. A series of Panda tests carried under controlled laboratory conditions in a calibration chamber were performed on sand tailings coming from three different dams. The following procedure was used:

a) Determination of the physical characteristics of the three samples of sand tailings (Table 1).

b) Perform dynamic cone penetration tests in a calibration chamber for different values of density to obtain the relation $\gamma d$ /qd (calibration curve). Figure 1 gives the calibration curves $\gamma d$ /qd obtained for sand tailings dam No. 1, No. 
2 and No. 3. A logarithmic relation can be observed, in agreement with previous results (Chaigneau, 2001) for this type of material.

c) Normalization of the dynamic cone resistance qd by atmospheric pressure (qdN1), with Cq $\leq 1.70$ (Equation 1).

d) The equivalence between the density (\% Standard Proctor) and the relative density (DR\%) was estimated for each calibration test. On the basis of the normalized dynamic cone resistance (qdN1), and by considering the classification adapted by Espinace, Villavicencio, \& Lemus (2013), we estimated the DR\% associated with each degree of compaction (Table 2).

e) An empirical model was adapted by using a simple regression on all the pairs of experimental data (qdN1, DR\%) for the three samples of sand tailings. Since we consider that sand tailings can be classified within a single geotechnical class, it is possible to estimate DR\% as a function of the resistance qdN1 by a single relation. The model used is given by the following equation:

$\mathrm{DR} \%=28.5 \cdot \ln \left(\mathrm{qd}_{\mathrm{N} 1}\right)-65.4 \quad \mathrm{r}^{2}=0,972$

with $1.0 \leq \mathrm{qdN} 1 \leq 326.0$

(2)

\begin{tabular}{|c|c|c|c|c|c|c|c|c|c|}
\hline \multirow[b]{2}{*}{$\begin{array}{l}\text { Geotechnical } \\
\text { properties }\end{array}$} & \multicolumn{3}{|c|}{ No. 1} & \multicolumn{3}{|c|}{ No. 2} & \multicolumn{3}{|c|}{ No. 3} \\
\hline & No of tests & Av. & $\mathrm{CV}$ & No of tests & Av. & $\mathrm{CV}$ & $\begin{array}{l}\text { No of } \\
\text { tests }\end{array}$ & Av. & CV \\
\hline$\gamma_{\mathrm{s}}$ & 9 & 3.09 & 4.6 & 6 & 3.36 & 8.0 & 11 & 3.1 & 2.2 \\
\hline$D_{50}$ & 3266 & 0.13 & 19.0 & 262 & 0.11 & 15.2 & 2958 & 0.25 & 8.7 \\
\hline F.C & 3266 & 28.0 & 28.7 & 262 & 33 & 26.3 & 2958 & 17 & 10.0 \\
\hline IP & 3266 & 0 & 0 & 262 & 0 & 0 & 2958 & 0 & 0 \\
\hline$\gamma_{\mathrm{dmax}}$ & 392 & 18.2 & 6.2 & 262 & 20.8 & 8.0 & 495 & 18.5 & 2.3 \\
\hline$\gamma_{d}$ & 3266 & 17.5 & 6.6 & 275 & 20.1 & 8.2 & 2958 & 18.1 & 2.9 \\
\hline$w_{\text {nat }}$ & 3266 & 11.0 & 22.3 & 275 & 3.3 & 43.1 & 2958 & 7.5 & 27.3 \\
\hline$q d$ & 275 & 4.8 & 50.6 & 75 & 2.87 & 45.9 & 100 & 1.95 & 52.8 \\
\hline $\mathrm{N}_{60}$ & 38 & 22 & 62.5 & 11 & 12 & 58.8 & - & - & - \\
\hline
\end{tabular}

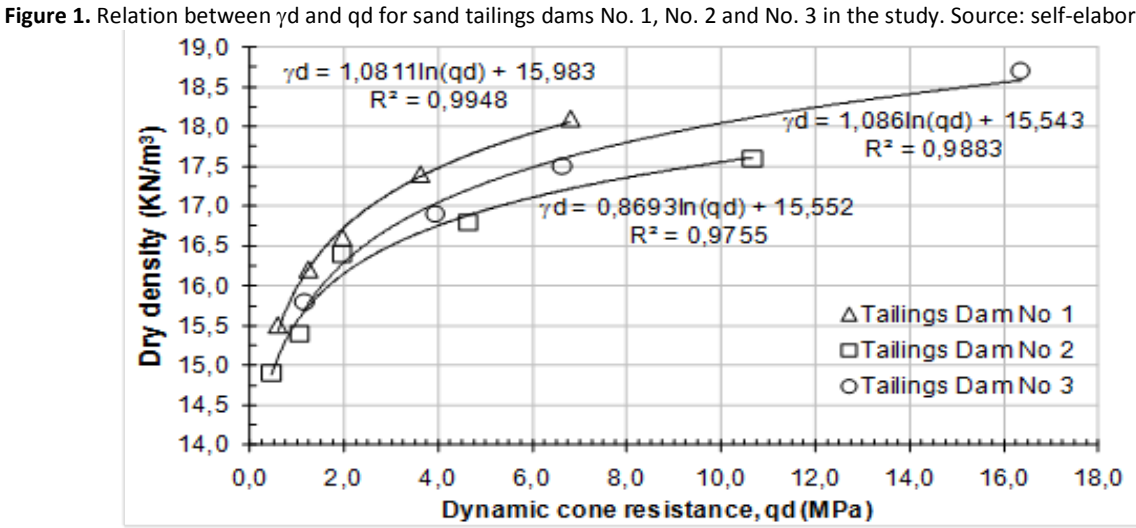

Figure 2 shows that the results of the model are very close to the experimental results. In addition, the relation proposed by Tatsuoka et al. (1990) was used by replacing qcN1 by qdN1. Figure 2 shows that the experimental points obtained by the dynamic penetrometer are also close to those calculated by using the expression provided by Tatsuoka et al. (1990). This result is in full agreement with work previously carried out on the correlation between qc and qd obtained with a Panda penetrometer. Indeed, it has been proven (Chaigneau, 2001; Lepetit, 2002) that in the case of sands and silty sands, the average value obtained for the ratio qd/qc is equal to 1.03 .

More recent research performed by Rahim, Prasad, \& George (2004) confirmed the relation between qd and qc. Their results obtained for granular soils have been demonstrated experimentally and analytically on the basis of the cylindrical cavity expansion theory and that of cavitation collapse. The resistance qd obtained with a light Panda penetrometer can therefore be assimilated with qc. In summary, in the case of sand tailings: (1) relative density (DR\%) can be deduced very precisely from the normalized dynamic cone penetration resistance qdN1 by a single relation, (2) the relation qdN1 = qcN1 is very well validated which allows using either static or dynamic penetrometers according to need. 
Figure 2. Relations proposed and references for estimating the relative density (DR\%) of sand tailings as a function of the normalized dynamic cone penetration resistance qdN1. Normalization exponent (c) equal to 0.75 Source: self-elaboration. 2014.

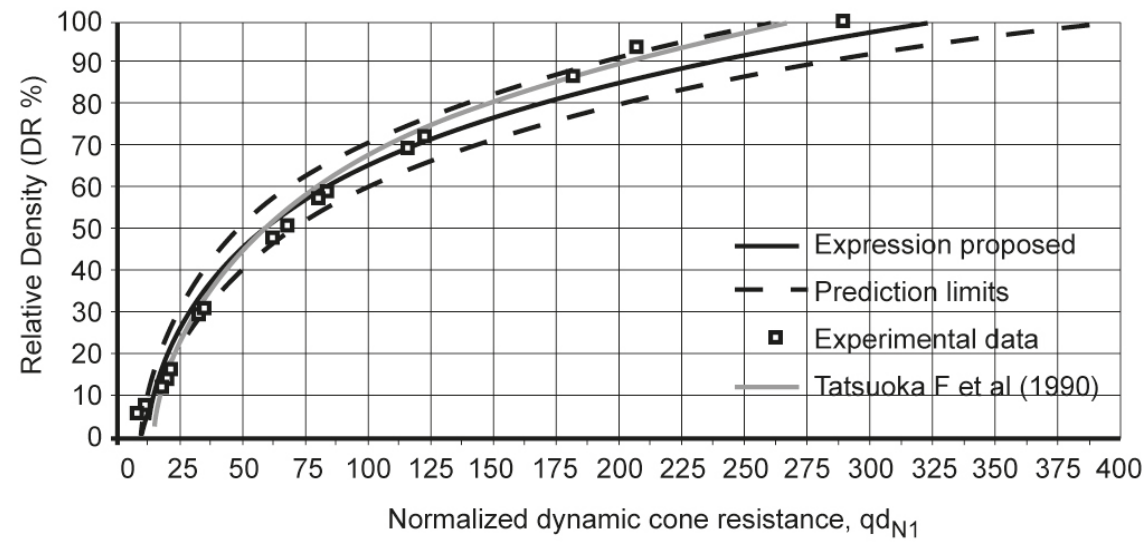

Table 2. Estimation of the state of compaction and associated mechanical behaviour for sand tailings. Source: Espinace et al., 2013.

\begin{tabular}{cccccc}
\hline $\mathbf{q d}_{\mathbf{N} 1}$ & \multicolumn{1}{c}{$\mathbf{N}_{\mathbf{1}} \mathbf{~}_{\mathbf{6 0}}$} & $\mathbf{D R} \%$ & State of compaction & Mechanical behaviour & Liquefaction potential \\
\hline$<20$ & $<8$ & $<20$ & Very low & Contractant & Very high \\
\hline $20-48$ & $8-15$ & $20-45$ & Low & Contractant & High \\
\hline $48-57$ & $15-20$ & $45-50$ & Compacted & Contractant & Equilibrium \\
\hline $57-81$ & $20-30$ & $50-65$ & Compacted to dense & Limit & Low \\
\hline $81-193$ & $30-50$ & $65-85$ & Dense & Dilatant & Very Low \\
\hline$>193$ & & $85-100$ & Very dense & Dilatant & Null \\
\hline
\end{tabular}

$\left(\mathrm{N}_{1}\right)_{60}$ : SPT blow count normalized to an overburden pressure of approximately $100 \mathrm{kPa}$ and a hammer energy ratio or hammer efficiency of $60 \%$

\section{Variability of relative density (DR\%) and associated mechanical behaviour}

On the basis of Equation 2, it is possible to estimate the profiles of the relative density (DR\%) as a function of depth from the penetrometer tests performed in situ (Fig. 3). The adaptation of the correlation presented in Table 2 allows estimation of the mechanical behaviour of sand tailings as a function of DR\%.

Figure 3. The breakdown into layers and relative density (DR\%). Test No. 1 performed in sand tailings dam No. 1. Source: self-elaboration. 2014

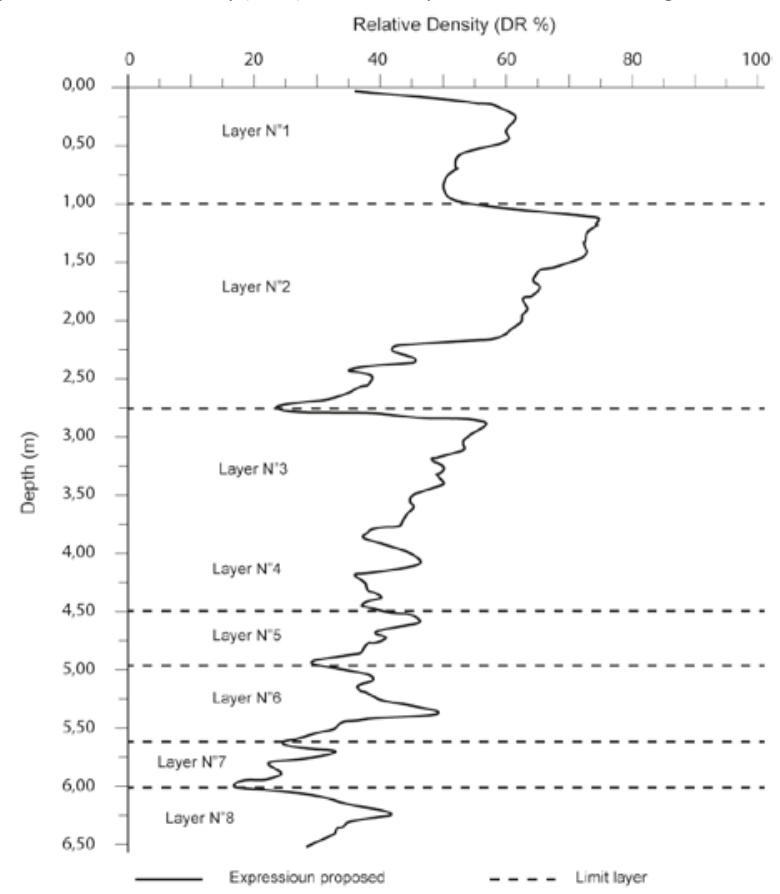


At the scale of the sand tailings dam and scale of each penetration test studied separately, the distribution of all these DR\% values can be adjusted by a normal probability model (see Fig. $4 \mathrm{a}$ and $4 \mathrm{~b}$ ). The results obtained agree with the compaction tests performed during the construction of the three sand tailings dams.

Figure 4. Distribution of DR\%. a) Sand tailings dams No. 1, No. 2 and No. 3 in the study. b) Test No. 1 performed in sand tailings dam No. 1. Source: self-elaboration. 2014.

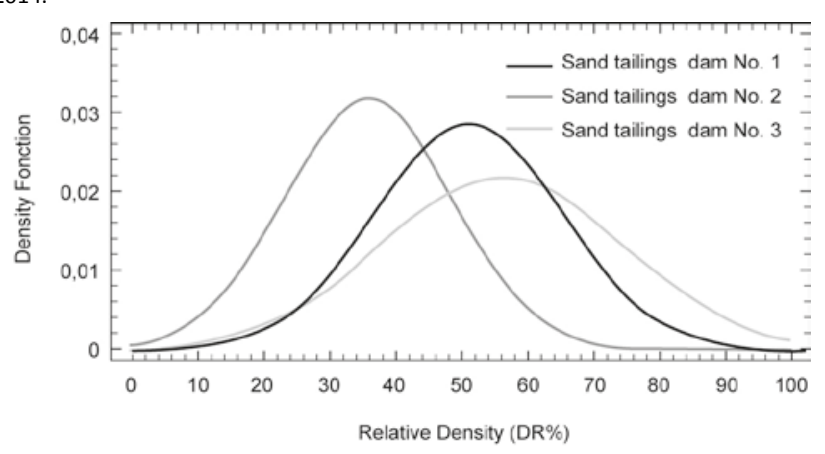

a)

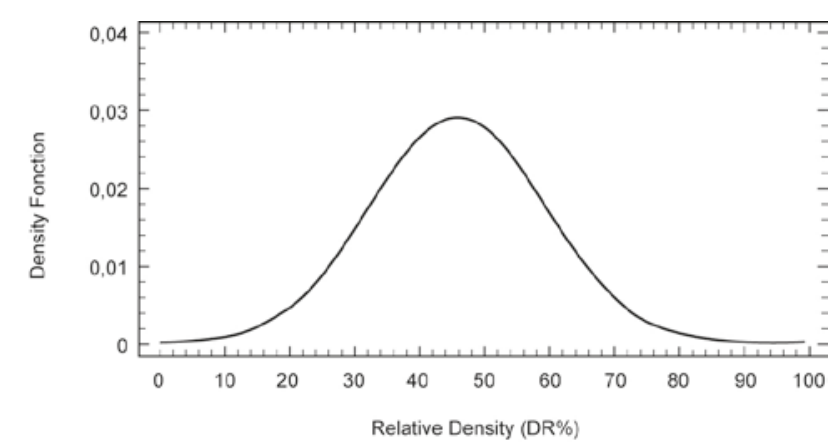

b)

The density function makes it possible to obtain a global idea of the mechanical behavior of the stored sand tailings, by considering the limit value of DR\%, which permits classifying contractant or dilatant behavior and associating in a qualitative way the liquefaction potential. As an example, Table 3 presents a probabilistic analysis at the sand tailings dam scale of the variability of DR\% and the mechanical behavior for the sand tailings dam No 1.

Table 3. Relative density (DR\%) and associated mechanical behavior. Sand tailings dam No. 1. Source: self-elaboration. 2014.

\begin{tabular}{|c|c|c|c|c|c|c|c|c|}
\hline \multicolumn{4}{|c|}{ Relative density, (DR\%) } & \multicolumn{5}{|c|}{ Analysis of the mechanical behavior } \\
\hline \multirow{2}{*}{ Average } & \multicolumn{2}{|c|}{ Values } & \multirow{2}{*}{$\begin{array}{l}\text { C.V } \\
(\%)\end{array}$} & \multirow{2}{*}{ DR\% } & \multirow{2}{*}{$\begin{array}{c}\text { Percentage of } \\
\text { values (\%) }\end{array}$} & \multirow{2}{*}{$\begin{array}{c}\text { State of } \\
\text { compaction }\end{array}$} & \multirow{2}{*}{$\begin{array}{l}\text { Mechanical } \\
\text { behaviour }\end{array}$} & \multirow{2}{*}{$\begin{array}{c}\text { Liquefaction } \\
\text { potential }\end{array}$} \\
\hline & Min. & Max. & & & & & & \\
\hline \multirow{3}{*}{52} & \multirow{3}{*}{17} & \multirow{3}{*}{94} & \multirow{3}{*}{28.27} & $15-55$ & 58 & Very low & Contractant & High \\
\hline & & & & $55-60$ & 13 & Dense & Contractant /Limit & Limiting \\
\hline & & & & $60-100$ & 29 & $\begin{array}{l}\text { Dense to very } \\
\text { dense }\end{array}$ & Dilatant & Null \\
\hline
\end{tabular}

The results are similar for the three dams. The variability of DR\% and the associated soil mechanics behavior, allows a first stage estimate of the liquefaction potential of sand tailings by statistical/probabilistic analysis performed considering the set of measures available for all dams or for each penetration test. Additionally it allows identification of the zones with lower strengths through a layer by layer penetration test.

\section{Probabilistic estimation of liquefaction potential}

Determination of DR\% provides an estimate of the mechanical behavior (contractant or dilatant) and liquefaction susceptibility of the sand tailings under seismic loading (Troncoso, 1986). An evaluation of the risk of liquefaction has been expressed in an equation formulated by Seed \& Idriss (1981). The classical method compares the ratio of the cyclic resistance of the soil (CRR) with the ratio of the cyclic shear stress ratio (CSR) stemming from seismic stress. The notion of liquefaction potential is therefore linked to the occurrence of the ratio CRR/CSR being lower than unity. It is widely accepted that estimating the cyclic resistance ratio (CRR) on the basis of dynamic and static penetration tests (Robertson \& Wride, 1998; Boulanger \& Idriss, 2004), requires taking into account the influence of vertical stress ( $\sigma^{\prime}$ v) and static shearing stress $(\alpha)$ on the CRR values by using correction factors.

\section{Relation used to estimate the CRR ratio from static (qc) and dynamic (qd) cone resistance}

The relation proposed by Robertson \& Wride (1998) to estimate the cyclic resistance ratio (CRR) of clean sands as a function of qcN1, was obtained by using a large compilation of existing data on the sites where superficial liquefaction effects had and had not been observed. In the case of silty sands with a percentage of fines higher than $5 \%$, these authors proposed reducing the normalized resistance values (qcN1 or qdN1) to an equivalent value of clean sand ( $q \mathrm{cN} 1 \mathrm{cs}$ or qdN1cs), by using a correction factor linked to the percentage of fines (Kc). The normalized and corrected cyclic resistance ratio $(C R R \sigma=1, \alpha=0)$ as a function of qc1Ncs is given by the equation: 


$$
\begin{aligned}
& \mathrm{CRR}_{\sigma=1 \alpha=0}=0.833 \cdot\left[\left(\mathrm{qc}_{\mathrm{N} 1}\right)_{\mathrm{CS}} / 1000\right]+0.05 \text { with }(\mathrm{qcN} 1) \mathrm{cs}<50 \quad \text { and } \\
& \mathrm{CRR}_{\sigma=1 \alpha=0}=93 \cdot\left[\left(\mathrm{q}_{\mathrm{C} 1}\right)_{\mathrm{CS}} / 1000\right]^{3}+0.08 \quad \text { with } 50 \leq(\mathrm{qcN} 1) \mathrm{cs} \leq 160
\end{aligned}
$$

The method proposed by Robertson \& Wride (1998) to evaluate liquefaction potential is applicable if the value of their Ic index (soil behavior type index) is less than 2.60. Classification of the material is always possible in the case of sand tailings used for building the body of a dam. Invariably, the nature of this type of material leads to its classification as a fine sand, a silty sand or a sandy silt, mainly as a function of the quantity of fines. By considering that Ic can be expressed as a function of the percentage of fines, as has been proposed by Robertson \& Wride (1998), we have obtained a relation between FC\% and Ic from the results of sand tailings stored in experimental dams, by using the following relation (equation 4):

$$
\text { Ic }=1.32+0.14 \cdot \sqrt{\mathrm{FC} \%} \quad \mathrm{r}^{2}=0.757
$$

Where: Ic is the soil behavior type index; FC\% is the percentage of fines smaller than 75 ( $\mu \mathrm{m})$. Therefore it is possible to apply the correction factor (Kc) proposed by Robertson and Wride (1998) and expressed as a function of Ic. In our case, the ratio $\mathrm{CRR} \sigma=1, \alpha=0$ is obtained from qdN1cs.

\section{Corrections to the cyclic resistance ratio CRR}

To correct the effect of vertical stress and static shearing stress (in the case of sloping ground), Boulanger \& Idriss (2004) proposed introducing adjustment factors $\mathrm{K} \sigma$ and $\mathrm{K} \alpha$ in the calculation of CRR, with $\mathrm{CRR}=\mathrm{CRR} \sigma=1, \alpha=0 \mathrm{~K} \sigma$. $\mathrm{K} \alpha$. Ratio $\mathrm{CRR} \sigma=1, \alpha=0$ is defined as the cyclic resistance ratio for a ratio of stresses $\left(\sigma^{\prime} \vee / \mathrm{pa}=1\right)$ and for a ratio of horizontal static shearing stresses equal to zero $\left(\alpha=\tau / \sigma^{\prime} v\right)$. To quantify the adjustment factors $(K \sigma$ and $K \alpha)$, considering the influence of relative density (DR\%) and confining stress $\left(\sigma^{\prime} v\right)$, we used the relations proposed by Boulanger \& Idriss (2004) by employing the parameter known as the relative state index ( $\xi R$ ), given by equation 5 .

$$
\xi_{\mathrm{R}}=\frac{1}{\mathrm{Q}-\ln \left(\frac{100 \cdot\left(1+2 \mathrm{~K}_{0}\right) \cdot \sigma_{\mathrm{v}}^{\prime}}{3 \mathrm{p}_{\mathrm{a}}}\right)}-\mathrm{DR}
$$

Where: $\xi R=$ relative state index; $Q=$ empirical constant dependent on the mineralogy and potential particle breakage (sand tailings, $Q=9$ ); $\mathrm{KO}=$ lateral pressure coefficient; $\sigma^{\prime} \mathrm{v}=$ vertical effective stress $(\mathrm{atm}) ; \mathrm{pa}=$ atmospheric pressure $(1.0 \mathrm{~atm}) ; \mathrm{DR}=$ relative density.

Use of $\xi R$ is a practical way to account for the influence of the relative density (DR) and the effective vertical stresses $\left(\sigma^{\prime} v\right)$ on the CRR ratio.

\section{Estimation of normalized cyclic stresses $(\mathrm{CSR})_{M=7,5}$}

To estimate the seismic stress ratio (CSR) normalized at a number of cycles equivalent to an earthquake of a magnitude 7.5 (CRS)M=7.5, we used the relation proposed by Seed \& Idriss (1981) and the work of Idriss (1999), given by equation 6 .

$$
(\mathrm{CSR})_{\mathrm{M}=7.5}=\frac{\mathrm{CSR}}{\mathrm{MSF}}=0,65\left(\frac{\mathrm{a}_{\max }}{\mathrm{g}}\right) \cdot\left(\frac{\sigma_{\mathrm{v}}}{\sigma_{\mathrm{v}}}\right) \cdot \frac{\mathrm{r}_{\mathrm{d}}}{\mathrm{MSF}}
$$


Where: $(\mathrm{CSR}) \mathrm{M}=7.5$ = cyclic stress ratio for an earthquake of magnitude 7.5; MSF = magnitude scaling factor (Idriss, 1999); amax = maximum horizontal acceleration at the ground surface; $\mathrm{g}=$ acceleration of gravity; rd = stress reduction coefficient (Boulanger \& Idriss, 2004); $\sigma \mathrm{v}=$ vertical stress (kpa); $\sigma^{\prime} \mathrm{v}=$ effective vertical stress $(\mathrm{kPa})$.

\section{Case of application}

To validate the proposed methodology, we analyzed another sector of the sand tailings dam No. 1 . The steps of the method used are as follows:

\begin{tabular}{ll} 
Table 4. General information and data of the project for sand tailings dam No. 1. Source: self-elaboration. 2014. \\
\hline Mining sector & $:$ Public mining company \\
\hline Type of tailings & $:$ Copper mine tailings \\
\hline Origin & $:$ Several mineral deposits \\
\hline Total volume & $: 10,200,000\left(\mathrm{~m}^{3}\right)$ \\
\hline Type of water cyclone & $:$ Conventional on the crest of the dam \\
\hline Type & $:$ Downstream construction \\
\hline Compaction & $:$ Mechanical by bulldozers \\
\hline Maximum dry density sand tailings & $: 18.6\left(\mathrm{kN} / \mathrm{m}^{3}\right)$ \\
\hline Target level of compaction & $: 95 \% \mathrm{SPMDD}$ (standard Proctor maximum dry density) \\
\hline Average height & $: 25.0(\mathrm{~m})$ \\
\hline Downstream slope & $: 1: 3.5(\mathrm{~V}: \mathrm{H})$ \\
\hline
\end{tabular}

a) General information on the sand tailings dam No. 1 (Table 4).

b) Generation of geotechnical data: the inspection points for performing the in-situ penetration tests were positioned in sectors where the controls have been performed during the dam filling phase. The profiles of the analysis were defined by considering the most unfavorable height and slope of the dam. The Panda dynamic penetrometer was used for the in-situ tests in the dam body carried out at specific geotechnical inspection points.

c) Relative properties and unit weights of the sand tailings stored (Table 1).

d) Estimation of maximum acceleration (amax): the maximum acceleration (amax) of the project is equal to $0.358 \mathrm{~g}$.

e) Variation of normalized cyclic stresses (CSR)M=7.5: by considering that the cyclic constraints are evaluated for an earthquake of constant magnitude and maximum acceleration, the variability of (CSR)M=7.5 depends on the variability of the stress reduction coefficient $(\mathrm{rd})$ as a function of depth and the ratio of local vertical stresses ( $\left.\sigma \mathrm{v} / \sigma^{\prime} \mathrm{v}\right)$. For a given depth, the ratio $\sigma v / \sigma^{\prime} v$ only depends on the variability of the density in-situ and the location of the phreatic surface. We then plotted the ratio (CSR)M=7.5 as a function of depth, for the minimum, average and maximum values of the ratio $\sigma \mathrm{v} / \sigma^{\prime} \mathrm{v}$ obtained experimentally, which will be introduced later in the calculation of the liquefaction Factor of Safety (F.S).

f) Estimation of the cyclic resistance ratio $C R R \sigma=1, \alpha=0$ : the analyses were performed, by considering the entire group of experimental data, and at for each test point. The following tables present the results of the statistical analyses performed. An analysis of histograms of groups of $C R R \sigma=1, \alpha=0$ values obtained at was performed in order to examine approximately if the general morphology of the histogram is compatible with a theoretical distribution. The results obtained are presented in Table 5.

\begin{tabular}{|c|c|c|c|c|c|c|c|c|}
\hline \multirow{3}{*}{$\begin{array}{l}\text { Test } \\
\text { No }\end{array}$} & \multirow{3}{*}{$\begin{array}{l}\text { Average } \\
\text { CRR }\end{array}$} & \multirow{3}{*}{ Std. deviation } & \multirow{2}{*}{\multicolumn{2}{|c|}{$\begin{array}{l}\text { Sourc } \\
\text { Values }\end{array}$}} & \multirow{3}{*}{$\begin{array}{l}\text { C.V } \\
(\%)\end{array}$} & \multirow{3}{*}{$\begin{array}{l}\text { Kolmogorov- } \\
\text { Smirnov test }\end{array}$} & \multirow{3}{*}{ Law distribution } & \multirow{3}{*}{$\alpha$ (error) } \\
\hline & & & & & & & & \\
\hline & & & Min. & Max. & & & & \\
\hline $1,2,3,4$ and 5 & 0.300 & 0.1506 & 0.026 & 0.712 & 50.1 & 0.049 & log-normal & $10 \%$ \\
\hline 1 & 0.281 & 0.1524 & 0.076 & 0.713 & 54.2 & 0.076 & log-normal & $10 \%$ \\
\hline 2 & 0.244 & 0.1242 & 0.026 & 0.736 & 50.8 & 0.073 & log-normal & $10 \%$ \\
\hline 3 & 0.299 & 0.1594 & 0.085 & 0.721 & 53.3 & 0.066 & log-normal & $10 \%$ \\
\hline 4 & 0.331 & 0.1413 & 0.112 & 0.713 & 42.8 & 0.064 & log-normal & $10 \%$ \\
\hline 5 & 0.387 & 0.1392 & 0.142 & 0.714 & 35.9 & 0.054 & log-normal & $10 \%$ \\
\hline
\end{tabular}

The results, allow a quantification of the variation of the cyclic strength coefficient of the stored sand tailings, at the dam level and at the layer level detected at each test point. This variation is the result of the variability of the particle sizes, of the unit weights and the corresponding estimated relative density (DR\%).

g) Estimation of the factor of safety (F.S): on the basis of the corrected and normalized cyclic resistance ratio (CSR)M= 7.5, obtained, the F.S against the occurrence of liquefaction is estimated. An analysis of histograms of F.S values obtained permitted an examination of whether the groups of data are compatible with a theoretical distribution function (Fig. 5a and 5b). 
Figure 5. The histograms and log-normal law of factor of safety (F.S). a) All tests performed in sand tailings dam No. 1. b) Test No 1 performed in sand tailings dam No. 1. Source: self-elaboration. 2014.

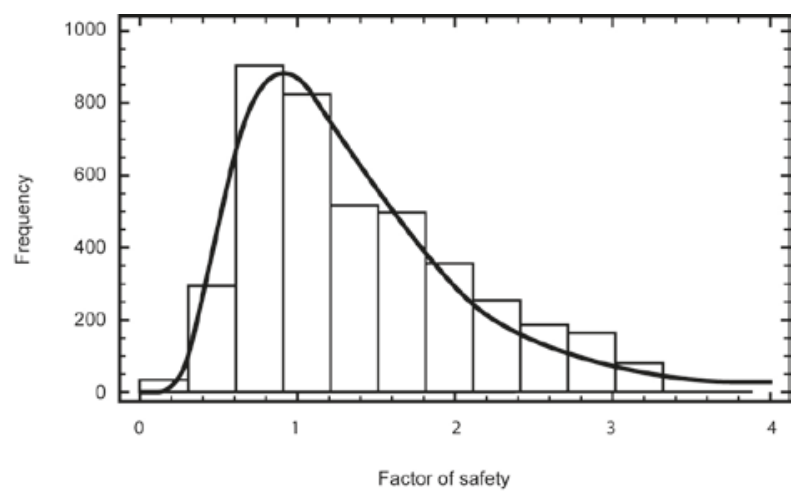

a)

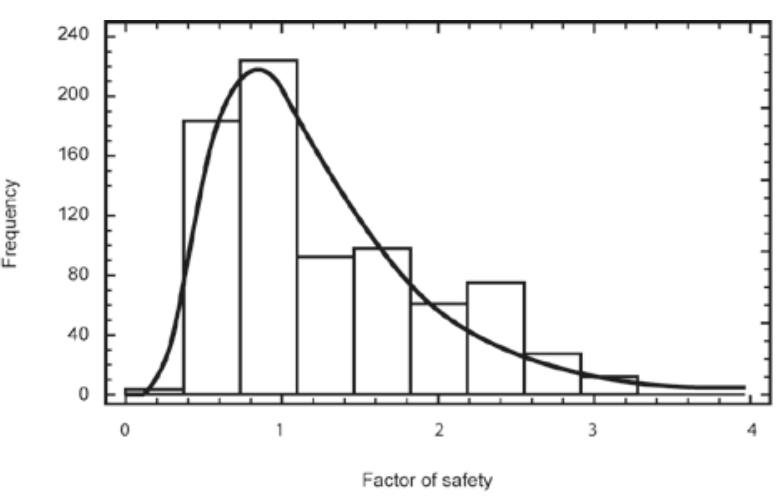

b)

The groups of F.S data stemming from sand tailings dam No 1 are reasonably well represented by a log-normal probability model. By using the distribution laws chosen, the probability of triggering the liquefaction phenomenon is obtained as the proportion of points for which FS $<1.0$. The results of statistical/probabilistic analyses obtained for all tests and for each test point, are presented in Table 6.

Table 6. Variation of the factor safety (F.S) obtained by $\mathrm{qd}_{\mathrm{N1cs}}$, and probability of failure by liquefaction. Sand tailings dam No. 1. Source: self-elaboration. 2014.

\begin{tabular}{cccccccc}
\hline $\begin{array}{c}\text { Test } \\
\text { No }\end{array}$ & Average & $\begin{array}{c}\text { Standard } \\
\text { deviation }\end{array}$ & $\begin{array}{c}\text { Coef. } \\
\text { Variation (\%) }\end{array}$ & $\begin{array}{c}\text { Kolmogorov- } \\
\text { Smirnov test }\end{array}$ & Law distribution & $\begin{array}{c}\alpha \\
\text { (error) }\end{array}$ & $\begin{array}{c}\text { Probability (\%) } \\
\text { F.S }<1.0\end{array}$ \\
\hline $1,2,3,4$ and 5 & 1.37 & 0.679 & 49.7 & 0.03 & log-normal & $10 \%$ & 38.7 \\
\hline 1 & 1.27 & 0.683 & 53.7 & 0.06 & log-normal & $10 \%$ & \\
\hline 2 & 1.11 & 0.556 & 50.2 & 0.07 & log-normal & $10 \%$ & 51.2 \\
\hline 3 & 1.35 & 0.716 & 52.9 & 0.06 & log-normal & $10 \%$ & 30.6 \\
\hline 4 & 1.53 & 0.646 & 42.3 & 0.11 & log-normal & $10 \%$ & $10 \%$ \\
\hline 5 & 1.75 & 0.626 & 35.8 & 0.05 & log-normal & $10 \%$ & \\
\hline
\end{tabular}

On the basis of the results obtained, we showed that:

- the method proposed for estimating liquefaction potential allows an evaluation of the probability of triggering this phenomenon, based on the variability of the geotechnical characteristics with the depth of sand tailings, in particular the resistance to penetration ( $q d N 1)$, relative state index $(\xi R)$ according to the relative density (DR\%), and associated mechanical behavior (dilatant or contractant),

- the results obtained on sand tailings dam No.1 (average height of 25.0m and downstream slope 1:3.5 V:H) , agree with the construction method employed and highlight its influence. Indeed, the high probability of failure due to liquefaction (F.S. $<1,0$ ) presented for the sand tailings dam analyzed, can be explained as the result of the sum of the following key factors:

- the sand tailings present in some sectors had a percentage of fines $(<75 \mu \mathrm{m})$ of more than $30 \%$. This can be explained as a consequence of the wrong cyclone process being employed at this operation.

- the layers identified from the analysis of the signals obtained from in situ Panda tests, show a layer thickness of at least $1.5 \mathrm{~m}$.

- the retaining dyke of the dam was only compacted by using a bulldozer, which resulted in practically no influence on the degree of compaction.

- the degree of in situ compaction is very low to average, as was shown in the Panda tests through the values obtained from the in depth relative density test. In the analyzed sectors DR\% was below $60 \%$, with a contractant mechanical behavior, and thus potentially liquefiable.

- this work does not take into account the hydraulic head or the actual water content at different depths. Thus the calculation must be corrected by the actual moisture content with depth data. However, on the sand tailings dam No 1 , the historical records of the piezometers do not show the existence of water, thus no correction was necessary.

- the analysis performed at a sand tailings dam level gave an overall idea of the liquefaction potential of the retaining dyke. At the scale of the volume covered by the penetration test used, the condition required for the risk analysis is that the phenomenon has to extend over a larger volume (e.g. to greater depth). Therefore, the probabilities calculated on the basis of the test points that liquefy locally do not fully reflect the actual risk of liquefaction. However, seeking the volume of influence was outside the scope of this work; analyses a calculation profile composed of a series of penetration tests permit estimation of potentially liquefiable areas by extrapolating their extension. 
It is suggested that it is necessary to carry out a probabilistic prediction of the behavior of sand tailings dams in order to manage the inherent risks. However, in practice, implementing this type of approach is limited by the difficulty of acquiring and managing the data to be used in reliability calculations. This paper proposed a method for estimating the in situ relative density (DR\%) and its variability, making it possible to carry out a probabilistic study of sand tailings dams stability. A single model was proposed for all similar mine tailings dams in Chile, with a view to linking a probability law to relative density (DR\%) variation and the associated mechanical behaviour. A method was proposed that takes into account the variability of data for performing a reliability calculation of liquefaction potential, the latter being the main cause for the failure of sand tailings dams.

On the basis of the results obtained, we showed that the proposed method for estimating liquefaction potential at sand tailings dam and test point levels permits an evaluation of the probability of triggering this phenomenon, by using the variability of the geotechnical characteristics of sand tailings and resistance to penetration (qdN1) in particular. A study of the spatial variability using models of random fields or analysis of variance reduction, is proposed as a continuation of this work.

\section{References}

Boulanger, R., \& Idriss, I. (2004). State normalization of penetration resistance and the effect of overburden stress on liquefaction resistance. In Proceedings 11th SDEE and 3rd ICEGE. Berkeley, CA.

Chaigneau, L. (2001). Caractérisation des mileux granulaires de surface à l'aide d'un pénétromètre. UNIVERSITE BLAISE PASCAL. CLERMONT II. France.

Espinace, R., Villavicencio, G., \& Lemus, L. (2013). The PANDA technology applied to design and operation of tailings dams. In Tailings2013. First International Seminar on Tailings Management. Santiago.

Idriss, I. (1999). An update to the Seed-Idriss simplified procedure for evaluating liquefaction potential. In Proceedings TRB Workshop on New Approaches to Liquefaction, FHWA-RD-99-165.

Lepetit, L. (2002). Etude d'une méthode de diagnostic de digues avec prise en compte du risque de liquéfaction. UNIVERSITE BLAISE PASCAL. CLERMONT II. France.

Moss, R. E. S., Seed, R. B., Kayen, R. E., Stewart, J. P., \& Der Kiureghian, A. (2006). CPT-Based Probabilistic Assessment of Seismic Soil Liquefaction Initiation. PEER Report 2005/15, (April). http://doi.org/PEER 2005/15

Olsen, R. ., \& Mitchell, J. (1995). CPT Stress normalization and prediction of soil classification (pp. 257-262). Linkoping.

Rahim, A., Prasad, S., \& George, K. (2004). Dynamic cone penetration resistance of soils-theory and evaluation. Geotechnical Engineering for Transportation, 1755-1766. http://doi.org/10.1061/40744(154)169

Robertson, P., \& Wride, C. (1998). Evaluating cyclic liquefaction potentialusing the cone penetration test. Canadian Geotechnical Journal, 35(3), 442-459.

Salgado, R., Boulanger, R., \& Mitchell, J. (1997). Lateral effects on CPT liquefaction resistance correlations. Journal of Geotechnical and Geoenvironmental Engineering, 123(8), 726-735. http://doi.org/10.1061/(ASCE)1090-0241(1997)123:8(726)

Seed, H., \& Idriss, I. (1981). Evaluation of liquefaction potential of sand deposits based on observations and performance in previous earthquakes. In Situ Testing to Evaluate Liquefaction Susceptibility, ASCE Annual Convention. St. Louis.

SERNAGEOMIN. (2010). Catastro de depósitos de relaves. Depósitos de relaves activos y no activos 2010.

Tatsuoka, F., Zhou, S., Sato, T., \& Shibuya, S. (1990). Evaluation method of liquefaction potencial and its application. Tokyo.

Troncoso, J. (1986). Envejecimiento y estabilidad sísmica de un depósito de residuos minerales en condición de abandono. Santiago.

Troncoso, J., \& Garcés, E. (2000). Ageing effects in the shear modulus of soils. Soil Dynamics and Earthquake Engineering, 19(8), 595-601. http://doi.org/doi:10.1016/S0267-7261(00)00066-X

Verdugo, R. (1997). Compactación de relaves. In IV Chilean Congress of Geotechnical Engineering. Valparaíso.

Verdugo, R., \& Bard, E. (1995). Maximum and minimum densities in non-cohesive soils. In Panamerican Conference on Soil Mechanics and Foundation Engineering (pp. 582-592). Guadalajara, México.

Villavicencio, G., Breul, P., Bacconnet, C., Boissier, D., \& Espinace, R. (2011). Estimation of the variability of tailings dams properties in order to perform probabilistic assessment. Geotechnical and Geological Engineering, 29(6), 1073-1084. http://doi.org/10.1007/s10706-011-9438-5

Villavicencio, G., Breul, P., Espinace, R., \& Valenzuela, P. (2012). Control de compactación con penetrómetros ligeros en tranques de relaves, considerando su variabilidad material y estructural. Revista de La Construcción, 11(1), 119-133.

Villavicencio, G., Espinace, R., Palma, J., Fourie, A., \& Valenzuela, P. (2014). Failures of sand tailings dams in a highly seismic country. Canadian Geotechnical Journal, 51(4), 449-464. http://doi.org/10.1139/cgj-2013-0142 